\title{
The
}

JOURNAL of ECONOMIC HISTORY

\section{PUBLISHED FOR}

THE ECONOMIC HISTORY ASSOCIATION

IN COOPERATION WITH

THE UNIVERSITY OF MICHIGAN

\section{HOFFMAN}

What Do States Do? Politics and Economic History

NICHOLAS

The Organization of Enterprise in Japan

BRAGUINSKY AND HOUNSHELL

Spinning Tales about Japanese Cotton Spinning: Saxonhouse (1974) and Lessons from New Data

HUMPHRIES AND WEISDORF

The Wages of Women in England, 1260-1850

ELI

Income Effects on Health: Evidence from Union Army Pensions

MiTCHENER AND WEIDENMIER

Was the Classical Gold Standard Credible on the Periphery?

Evidence from Currency Risk

GAZELEY, NeWELl, AND BEZABIH

The Transformation of Hunger Revisited: Estimating Available Calories from the Budgets of Late Nineteenth-Century British Households

LOGAN

The Transformation of Hunger Revisited: Reply 


\title{
THE JOURNAL OF ECONOMIC HISTORY
}

ISSN 0022-0507

\author{
Published for the Economic History Association in Cooperation with the University of Michigan \\ by Cambridge University Press
}

EDITORS

\author{
PAUl W. Rhode ANN M. CARlos \\ EDITORIAL ASSOCIATES \\ TIMOTHY GUINNANE JOHN MURRAY \\ EDITORIAL STAFF \\ FAN FEI AND LILY WELCH, ASSISTANT EDITORS \\ SALLY SZTRECSKA, PRODUCTION EDITOR \\ PRICE V. FISHBACK, EHA EXECUTIVE DIRECTOR \\ EDITORIAL BOARD
}

\author{
Ran Abramitzky, Stanford University \\ Hoyt Bleakley, University of Michigan \\ Leah Boustan, University of California, Los Angeles \\ Joyce Burnette, Wabash College \\ Bruce Campbell, The Queen's University of Belfast \\ Benjamin Chabot, Federal Reserve Bank of Chicago \\ Marc Flandreau, The Graduate Institute, Geneva \\ Bishnupriya Gupta, University of Warwick \\ Michael Huberman, Université de Montréal \\ Juliette Levy, University of California, Riverside \\ Frank Lewis, Queens University, Canada \\ Trevon Logan, The Ohio State University
}

Carlos Marichal, El Colegio de México

Joseph Mason, Louisiana State University Chiaki Moriguchi, Hitotsubashi University Anne Murphy, University of Hertfordshire John E. Murray, Rhodes College

Tom Nicholas, Harvard Business School

Alan L. Olmstead, University of California, Davis

Jonathan Rose, Federal Reserve Board

Francesca Trivellato, Yale University

Patrick Wallis, London School of Economics

Kirsten Wandschneider, Occidental College

Nikolaus Wolf, Humboldt University, Berlin

Aims and Scope: The Journal of Economic History seeks to promote the scholarly study of economic aspects of the human past from a diversity of perspectives, notably those of economists and historians. By encouraging careful formulation of issues and clear exposition of methods, the JOURNAL hopes to stimulate discourse among scholars with varied interests and modes of inquiry. The JOURNAL is abstracted in EconLit, e-JEL, JEL on CD, Sociological Abstracts, Elsevier Geo Abstracts, and Scopus. Back issues of the JouRNAL (5-years-old and older) are available on-line to JSTOR subscribers. Http://JSTOR.ORG.

Instructions for Contributors: Articles on economic history and related aspects of history or economics will be considered for publication by the Editors on the understanding that the articles have not previously been published and are not under consideration elsewhere. Papers should indicate the wider significance of detailed original research findings as well as the logic and limitations of specialized techniques of analysis. Comments and shorter notes are also welcome. The JOURNAL does not accept unsolicited book reviews, nor can it honor requests to review particular works. Contributions should be kept within 35 double-spaced pages, inclusive of footnotes, references, figures, and tablesapproximately 15,000 words. A submission fee, payable to the Economic History Association, of $\$ 60.00$ or a year's membership (fee schedule below) is required from nonmembers of the Association.

How to Submit a Paper for Consideration: Log into http://mc.manuscriptcentral.com/jeh and follow the instructions there. Choose Editor Ann Carlos for submissions dealing with the Eurasian Land Mass; choose Editor Paul Rhode for submissions dealing with the Americas, Africa, and Australasia. Upload files (completely blinded of identifying information) as Word, WordPerfect, or Excel documents.

Editorial Office Addresses: Paul Rhode, Editor; Journal of Economic History; jo-econ-hist@ umich.edu; Department of Economics, University of Michigan, 205 Lorch Hall, 611 Tappan, Street, Ann Arbor, Michigan 48109-1220. Ann M. Carlos, Editor; Journal of Economic History; ann.carlos@colorado.edu; Department of Economics, University of Colorado, 256 UCB, Boulder, CO 80309. For style sheets and general inquiries: Paul Rhode, Editor; Journal of Economic History; jo-econ-hist@umich.edu; Department of Economics, University of Michigan, 205 Lorch Hall, 611 Tappan, Street, Ann Arbor, Michigan 48109-1220. 734-647-5603.

Association Office Address and Membership Information: Individuals who are members of the Economic History Association receive online access to the JOURNAL as part of their annual dues. Membership rates (in U.S. dollars) are $\$ 60.00 *$ for those with income above $\$ 50,000$ a year; $\$ 35.00$ for those with income below $\$ 50,000 ; \$ 20.00$ for students and for professors emeriti* who have been members of the Association for ten years; $\$ 1,200.00$ or 20 times the annual rate for life membership. Payment of additional $\$ 32.00$ permits joint membership with the Economic History Society (UK). Applications and inquiries concerning membership should be addressed to the Economic History Association, Department of Economics, University of Arizona, Tucson, AZ 85721. Telephone: 520-621-4421. E-mail: pfishback@eller.arizona.edu. EHA members should send changes of address to the association office. * Regular and Emeriti members wishing to receive the printed version of the JOURNAL may pay an additional \$10 annually.

Subscription, Publishing, and Advertising Office Address: Cambridge University Press, 32 Avenue of the Americas, New York, NY 10013-2473, U.S.A.; or Cambridge University Press, The Edinburgh Building, Shaftesbury Road, Cambridge CB2 8RU, England.

Subscription Information: The Journal of Economic History is published quarterly in March, June, September, and December. Annual institutional print-and-electronic subscription rate (2015) is US \$364 in the U.S.A., Canada, and Mexico, UK £223 + VAT elsewhere. Annual institutional electronic-only subscription rate (2015) is US \$295, UK £182 + VAT elsewhere. Annual institutions print-only subscription rate (2015) is US \$342, UK $£ 211$ + VAT elsewhere. Individuals subscribe by becoming a member of the EHA. Prices include surface postage and insurance.

\section{Copyright (C) 2015 The Economic History Association}

All rights reserved. No part of this publication may be reproduced, in any form or by any means, electronic, photocopy, or otherwise, without permission in writing from Cambridge University Press. For further information see http://us.cambridge.org/information/rights/. Photocopying information for users in the U.S.A.: The Item-Fee Code for the publication (0022-0507/15 \$15.00) indicated that copying for internal or personal use beyond that permitted by Sec. 107 or 108 of the U.S. Copyright Law is authorized for users duly registered with the Copyright Clearance Center (CCC) Transaction Reporting Service, provided that the appropriate remittance of $\$ 15.00$ per article is paid directly to CCC, 222 Rosewood Drive, Danvers, MA 01923. Specific written permission must be obtained for all other copying.

The Journal of Economic History (USPS 279-580) is published quarterly by Cambridge University Press. Periodicals postage paid at New York, NY and additional mailing offices. Postmaster: Send address changes to The Journal of Economic History, Cambridge University Press,

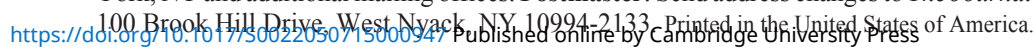




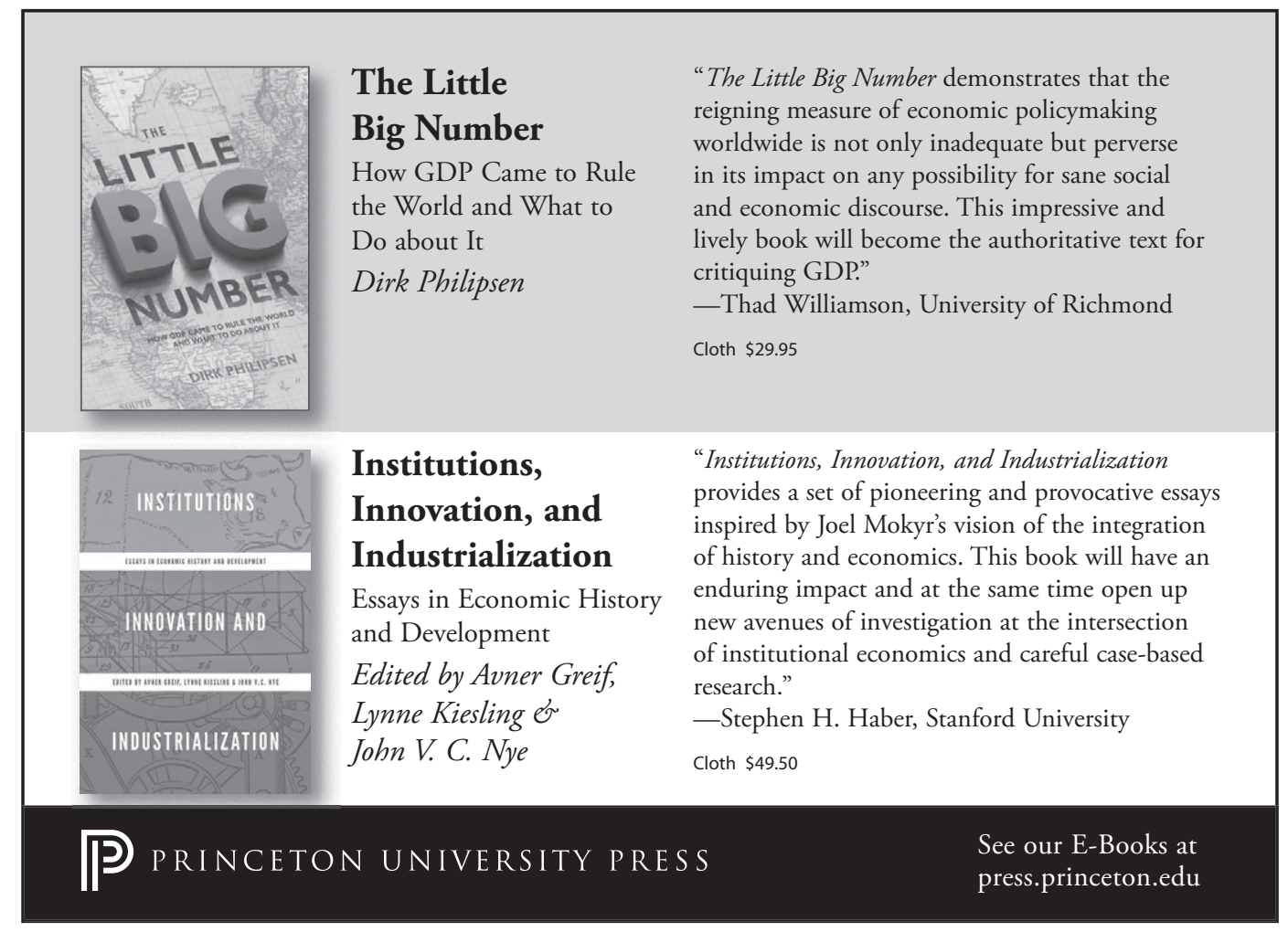




\section{CAMbridge}

\section{Our Best in Economic History}
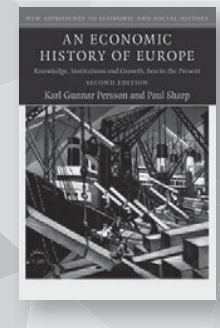

\section{An Economic History} of Europe*

Knowledge, Institutions and Growth, 600 to the Present SECOND EDITION

Karl Gunnar Persson and Paul Sharp

New Approaches to Economic and Social History

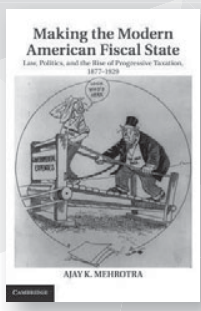

Making the Modern American Fiscal State*

Law, Politics, and the Rise of Progressive Taxation, 1877-1929 Ajay K. Mehrotra Cambridge Historical Studies in American Law and Society
Masters, Slaves, and Exchange*

Power's Purchase in the Old South

Kathleen M. Hilliard

Cambridge Studies on

the American South

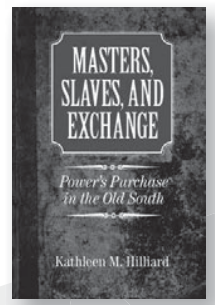

Cambridge Studies in Economic History - Second Series

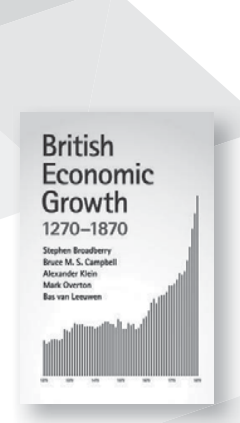

\section{British Economic} Growth, 1270-1870*

Stephen Broadberry, Bruce Campbell, Alexander Klein, Mark Overton, and Bas van Leeuwen

\section{Cotton*}

The Fabric that Made the Modern World

Giorgio Riello
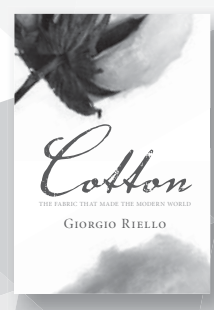

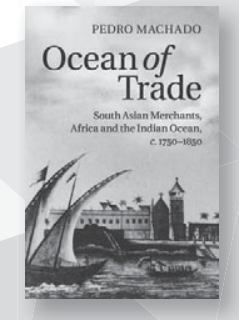

\section{Ocean of Trade}

South Asian

Merchants, Africa and

the Indian Ocean,

c. 1750-1850

Pedro Machado

\section{Western Union and the Creation of the American Corporate Order, 1845-1893* \\ Joshua D. Wolff}

*Available in paperback

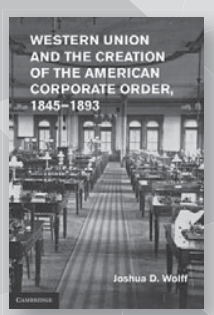

order online at cambridge.org/history

follow us @cambUP_History 
